\title{
Małgorzata Lempart
}

Institute of Geological Sciences, Polish Academy of Sciences, Kraków

Małgorzata Labus

Institute of Applied Geology, Silesian University of Technology, Gliwice

\section{Differential scanning calorimetry (DSC) in researching the mineral carbonation processes of cement materials, in terms of $\mathrm{CO}_{2}$ sequestration}

\begin{abstract}
Mineral carbonation is one of the mitigation strategies considered for reducing atmospheric $\mathrm{CO}_{2}$ concentrations. The reuse of industrial solid wastes and residues (e.g. waste building material, including cement - which readily sequester $\mathrm{CO}_{2}$ at ambient temperatures and pressures) is often taken into consideration. The main barrier to the use of mineral carbonation is the rather slow reaction progress. Based on a literature review it has been hypothesized, that knowledge of the reaction energy of formation and disintegration of carbonate phases is needed, and differential scanning calorimetry (DSC) measurement method could be used to obtain thermodynamic data of the mineral carbonation process.
\end{abstract}

Key words: mineral carbonation, cement, differential scanning calorimetry, enthalpy.

\section{Zastosowanie skaningowej kalorymetrii różnicowej (DSC) w badaniach procesu mineralnej karbonatyzacji w materiałach cementowych w aspekcie sekwestracji $\mathrm{CO}_{2}$}

\begin{abstract}
Mineralna karbonatyzacja jest jedną z wielu rozważanych metod, zmierzających do ograniczenia stężenia $\mathrm{CO}_{2} \mathrm{w}$ atmosferze. Odpowiednim do wykorzystania $\mathrm{w}$ tym procesie materiałem wydają się odpady przemysłowe (np. gruz budowlany, zawierający cement, który łatwo sekwestruje $\mathrm{CO}_{2}$ w warunkach atmosferycznych). Główną barierą w stosowaniu na szerszą skalę tego rodzaju sekwestracji jest powolny postęp reakcji. Analiza literaturowa wskazuje na istniejące braki dotyczące energii reakcji tworzenia i rozpadu faz węglanowych (szczególnie - entalpii $\Delta H$ ) w zależności od warunków procesu. W artykule wskazano na możliwość zastosowania skaningowej kalorymetrii różnicowej (DSC) do wyznaczenia danych termodynamicznych procesu karbonatyzacji materiału cementowego.
\end{abstract}

Słowa kluczowe: Mineralna karbonatyzacja, cement, skaningowa kalorymetria różnicowa, entalpia.

\section{Introduction}

Anthropomorphic $\mathrm{CO}_{2}$ emission has increased dramatically in the last 100 years, and in the absence of changes in technology, $\mathrm{CO}_{2}$ emissions will continue to increase. Among the different options of reduction of $\mathrm{CO}_{2}$ concentration in the atmosphere, mineral carbonation is regarded as a good possible way for $\mathrm{CO}_{2}$ sequestration. Carbon dioxide sequestration includes a mechanism of the $\mathrm{CO}_{2}$ separation from the emitted stream of gas and its safe storage [8, 32]. Underground storage of $\mathrm{CO}_{2}$ is a very complicated and expensive process, hence carbon dioxide capture and storage (CCS) with the use of mineral carbonation is one of the mitigation strategies more often considered for reducing atmospheric $\mathrm{CO}_{2}$ concentrations [18].

The mineral carbonation is based on the reaction of $\mathrm{CO}_{2}$ with a metal oxide and the transformation into $\mathrm{CaCO}_{3}$, $\mathrm{MgCO}_{3}, \mathrm{CaMg}\left(\mathrm{CO}_{3}\right)_{2}, \mathrm{FeCO}_{3}$ and other thermodynamically stable forms. The consideration of formation pathways and the thermodynamic stability of these carbonate minerals are 
essential to understand the sequestration processes. Therefore, a calculation of the thermodynamic data is required to understand the geochemical reactions associated with $\mathrm{CO}_{2}$ sequestration. It should be possible to determine the crystallization energy of carbonate minerals and the characteristics of the crystallization process in the specific conditions of temperature and pressure, to help to fill the gaps in the kinetic and thermodynamic data concerning minerals carbonation products. For calculating and determining: the specific heat capacity $\left(C_{p}\right)$, enthalpy $(\Delta H)$, entropy $(\Delta S)$ and Gibbs free energy $(\Delta G)$ thermogravimetry and differential scanning calorimetry (TG/DSC) can be used as suitable methods.

\section{Mineral carbonation - significance and methods}

Mineral carbonation is a process involving dissolution of $\mathrm{CO}_{2}$ and its transformation into $\mathrm{CaCO}_{3}, \mathrm{MgCO}_{3}, \mathrm{CaMg}\left(\mathrm{CO}_{3}\right)_{2}$, $\mathrm{FeCO}_{3}$ and other minerals. Because of the thermodynamic stability of the carbonate products, mineral $\mathrm{CO}_{2}$ sequestration is an attractive means for reducing carbon dioxide emission. In order to maximize the effectiveness of $\mathrm{CO}_{2}$ mineral sequestration, a thorough understanding of the initial stages of formation and subsequent crystallization of the mentioned carbonate minerals is required $[11,19,28]$.

In natural conditions carbonation appears through geologic processes of silicate weathering, however the reaction rates are slow (on geologic time scales) and the economic feasibility of its wide-spread application is not fully known. A mineral carbonation process through binding $\mathrm{CO}_{2}$ with natural mineral such as talc or serpentine is known in a hipergenic environment:

$$
\begin{gathered}
\mathrm{CaSiO}_{3} \text { (wollastonite) }+2 \mathrm{CO}_{2}+\mathrm{H}_{2} \mathrm{O} \rightarrow \\
\rightarrow \mathrm{Ca}^{2+}+2 \mathrm{HCO}_{3}^{-}+\mathrm{SiO}_{2}
\end{gathered}
$$

and next $\mathrm{CaCO}_{3}$ is forming:

$$
\mathrm{CaSiO}_{3}+\mathrm{CO}_{2} \rightarrow \mathrm{CaCO}_{3}+\mathrm{SiO}_{2}
$$

This reaction has become the base for considerations about mineral carbonation processes with the use of the mineral resources [30]. The stability of the endproducts (i.e. carbonates), however, has prompted investigations into ways to mimic and catalyze the weathering process in the laboratory [3, 12]. Mineral carbonation research is concentrated on the sequestration in: deep saline aquifers, mined silicate minerals e.g. serpentine $\left(\mathrm{Mg}_{3} \mathrm{Si}_{2} \mathrm{O}_{5}(\mathrm{OH})_{4}\right)$, talc $\left(\mathrm{Mg}_{3} \mathrm{Si}_{4} \mathrm{O}_{10}(\mathrm{OH})_{2}\right)$, olivine $\left(\mathrm{Mg}_{2} \mathrm{SiO}_{4}\right)$, wollastonite $\left(\mathrm{CaSiO}_{3}\right)$ or alkaline waste material. In case of natural silicate materials, both the mineral acquisition and pre-processing steps require energy inputs, which reduces the overall efficiency of the process of $\mathrm{CO}_{2}$ sequestration $[1,13,17]$. In contrast to these sources, the reuse of industrial solid wastes and residues, rich in calcium and/or magnesium, is more readily available (Fig. 1).

The carbonation of alkaline waste, such as coal fly ash, municipal solid waste incinerator ash, cement kiln dust and steel slag has been investigated in many experiments $[3,12]$. Carbonation of waste has been proved to be an effective process, when waste is alkaline-rich, in the form of calcium or magnesium oxides. Many fine-grained industrial wastes, such as those mentioned above, have high mass percentages of $\mathrm{CaO}$. Mineral carbonation is an exothermic process, hence the energy released could be used in other processes. The oxide content and high surface area of alkaline wastes make them potentially suitable for carbonation reactions without the need for extensive preprocessing [7, 10, 12, 18, 27, 30, 31]. The use of industrial wastes, e.g., steelmaking slag or cement kiln dust, in the carbonation process can accelerate the carbonation reaction due to their high reactivity with $\mathrm{CO}_{2}$ and typically calcium rich contents, which makes them suitable materials for carbonation reaction. Carbonation is also an effective way to improve the durability of concrete because relatively insoluble $\mathrm{CaCO}_{3}$ is formed from the soluble $\mathrm{Ca}(\mathrm{OH})_{2}$. The reaction could permanently bind $\mathrm{CO}_{2}$ with carbonates, while

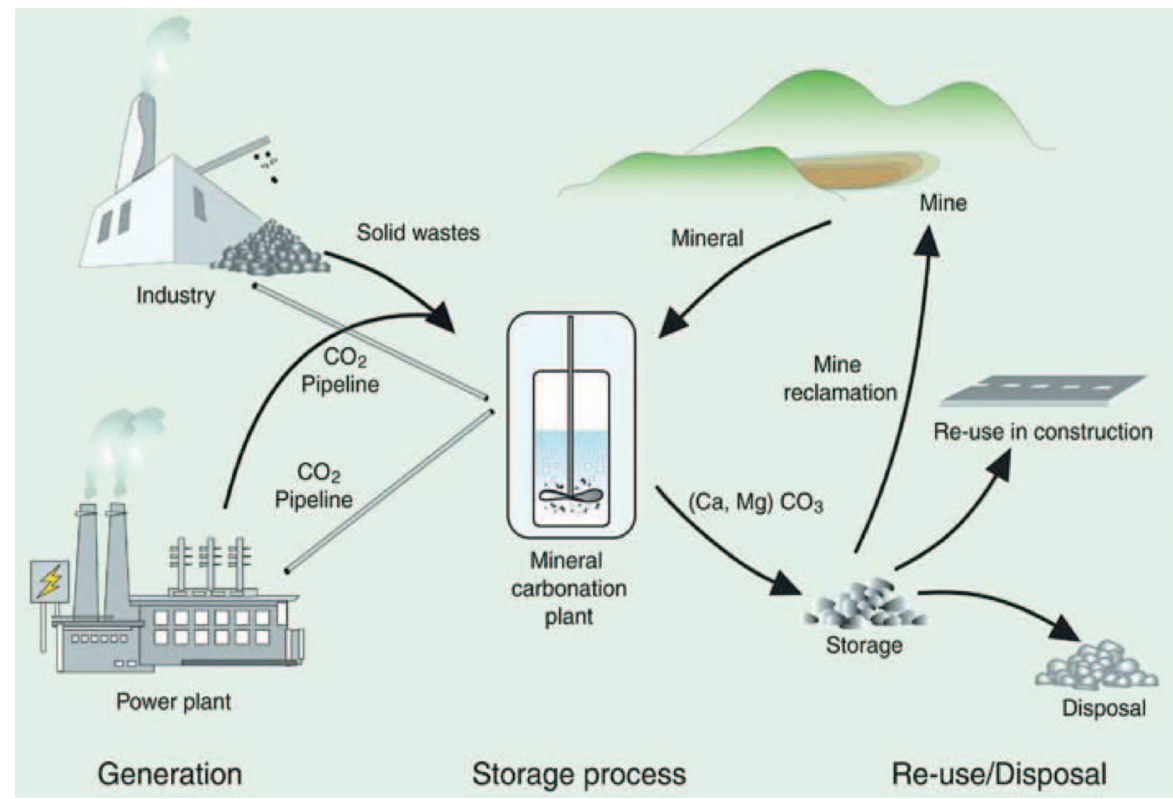

Fig. 1. Process steps associated with the ex-situ mineral carbonation of silicate rocks or industrial residues [19] 
at the same time strengthen the waste material [3]. Moreover, the impacts of the formation of $\mathrm{CaCO}_{3}$ on the stability of the waste material have also been investigated, particularly for its reduction of $\mathrm{pH}$ and the immobilization of the heavy metals, such as $\mathrm{Cd}, \mathrm{Pb}$, and $\mathrm{Cr}[6,26]$.

Due to the high content of $\mathrm{CaO}$ in cement slurries, especially of Portland cement or concrete waste, they become very good sequestering materials $[3,11]$. Waste building material, including cement, readily sequester $\mathrm{CO}_{2}$ at ambient temperatures and pressures. Portlandite $\mathrm{Ca}(\mathrm{OH})_{2}$ is an important component in cement to be used in concrete injection systems for geological storage of $\mathrm{CO}_{2}$. Cement carbonation is the main chemical transformation occurring in borehole materials in contact with $\mathrm{CO}_{2}$. This process could be the cause of a possible loss of borehole integrity, inducing leakage of gas to the surface [20].

In simple terms, the one step process of mineral carbonation involves the reaction of $\mathrm{CO}_{2}$, which penetrates through the pores of the waste material, with the following compounds having the greatest potential for the reaction: $\mathrm{Ca}(\mathrm{OH})_{2}$, $\mathrm{Mg}(\mathrm{OH})_{2}, \mathrm{FeCl}_{2}, \mathrm{KOH}$ or $\mathrm{NaOH}$. It is worth mentioning that the degree of cement carbonation depends on its saturation with water, which facilitates the dissociation to bicarbonate and $\mathrm{H}^{+}$ions. The results obtained by Mądrawski et al. [18], who performed experiments on recycled concrete aggregates, showed that carbonation rate increased with increasing water to cement ratio $(\mathrm{w} / \mathrm{c})$.

The carbonation reactions are as follows [11]:

$$
\begin{gathered}
\mathrm{CO}_{2}+\mathrm{H}_{2} \mathrm{O} \rightarrow \mathrm{H}_{2} \mathrm{CO}_{3} \rightarrow \mathrm{HCO}^{3-}+\mathrm{H}^{+} \\
\mathrm{CO}_{2}+\mathrm{H}_{2} \mathrm{O} \rightarrow 2 \mathrm{H}_{(\mathrm{aq})}{ }^{+}+\mathrm{CO}_{3(\mathrm{aq})} \\
\mathrm{CaO}+\mathrm{H}_{2} \mathrm{O} \rightarrow \mathrm{Ca}(\mathrm{OH})_{2} \\
\mathrm{Ca}(\mathrm{OH})_{2} \rightarrow \mathrm{Ca}_{(\mathrm{aq})}^{2+}+2 \mathrm{OH}_{(\mathrm{aq})} \\
\mathrm{Ca}_{(\mathrm{aq})}{ }^{2+}+\mathrm{CO}_{3(\mathrm{aq})}{ }^{2-} \rightarrow \mathrm{CaCO}_{3}
\end{gathered}
$$

Mineral carbonation process, taking place under standard conditions of temperature and pressure, despite the thermodynamic stability of its products, is very slow [10, 19]. Poorly known reaction kinetics becomes a barrier in the application of this method on a wider scale $[22,29]$. The major product of the carbonation is calcite, probably in both crystalline and amorphous form. In order to determine the reaction pathways and products detailed measurements and thermodynamic characteristic of pre- and post-carbonation materials are needed [28].

\section{Current state of knowledge of carbonation reaction thermodynamics}

Many researchers attempt to develop technologies and methods of mineral carbonation, which will speed up the process $[2,10,14]$. Regrettably, in many cases the thermodynamic conditions of a system of the chemical reactions and physicochemical processes is not considered. However, the energies of creation and dissolution of carbonate minerals formed in the process of carbonation in different conditions of pressure and temperature should be carefully considered [28].

Krupka et al. [16], as well as Regnault [25], show deficits in kinetic and thermodynamic data of precipitating minerals. Frequently, due to lack of data, mineral carbonation reaction is compared to the carbonation occurring in the hypergenic environment. Moreover, what is used is the thermodynamic data for the pure carbonate phase synthesized in the laboratory or found in the hypergenic environment [16]. There is also the need for more precise mineralogical and geochemical characteristics of the carbonates, formed in geological systems affected by human activities. Therefore, it is required to determine the energy of crystallization of carbonate phases formed and to thoroughly investigate the carbonation reaction.

Radha et al. [23] and Sel et al. [28] have paid attention to how significant is understanding the physics and chemistry of the initial stages of formation and subsequent crystallization of carbonate minerals on the molecular scale. The thermodynamic stability of the carbonation product and its crystallization energetics play an important role in mineralization. Radha et al. [23] investigated the energetics and structure of synthetic amorphous $\mathrm{Ca}-\mathrm{Mg}$ carbonates, which are also formed during mineral carbonation. Sel et al. [28] determined the thermodynamic parameters for the synthetic amorphous phase of iron carbonates which are formed in the process of $\mathrm{CO}_{2}$ sequestration. They determined the crystallization enthalpy $\left(\Delta H_{\text {crys }}\right)$ of the synthetic carbonate phase with the use of differential scanning calorimetry (DSC). Sel et al. [28] applied a methodology called drop-solution calorimetry and measured the enthalpy of drop-solution $\left(\Delta H_{\text {dropsolution }}\right)$. This method will be explained in the next section. Comparison of the results indicated that enthalpy of crystallization in the carbonate systems is a function of the metal ion size. Comparison of the crystallization energetics of amorphous $\mathrm{FeCO}_{3}$ to other amorphous carbonate systems is pertinent here. Amorphous $\mathrm{FeCO}_{3}$ is energetically similar to amorphous $\mathrm{MgCO}_{3}$ and more metastable than amorphous $\mathrm{CaCO}_{3}$. Since the ionic radii of $\mathrm{Mg}^{2+}$ and $\mathrm{Fe}^{2+}$ are similar but smaller than that of $\mathrm{Ca}^{2+}$, this finding may reveal a direct relationship between $\Delta H_{\text {crystallization }}$ and the ionic size of $\mathrm{M}^{2+}$. This example shows how valuable is the insight provided by the analysis of crystallization energy and its comparison with a number of other properties. 
Attention should be paid to the lack of thermodynamic and kinetic data, especially for precipitating minerals in mineral $\mathrm{CO}_{2}$ sequestration processes with use of cement material. Consideration of the pathways of reactions and the chemical behavior of forming carbonates, regarding different environment systems is required. Each carbonation system differs in the composition of the involved phases and conditions of the reaction; the enthalpy change for the reaction depends on the state of the reactants and products, and system conditions. In the case of carbonation reaction of cement material, the $\mathrm{Ca}(\mathrm{OH})_{2}$ present in the cementitious matrix as well as calcium silicate hydrates $(\mathrm{C}-\mathrm{S}-\mathrm{H})$ react with $\mathrm{CO}_{2}$, mainly in the early hydration stages, forming calcium carbonate $\left(\mathrm{CaCO}_{3}\right)$, depending on process parameters [14]. Therefore the determination of the enthalpy of crystallization of the carbonate phases is necessary. In order to determine thermodynamic data the specific heat capacity $\left(C_{p}\right)$, enthalpy $(\Delta H)$, entropy $(\Delta S)$ and Gibbs free energy $(\Delta G)$, will be used in the future for the modeling of mineral carbonation under certain conditions. The calculated kinetic data, in particular activation energy $E_{a}$ will allow for the comparison of the rate at which a reaction proceeds, and may help in finding methods for the maximization of the effectiveness of the carbonation process. Still, there is no real transformation model of cement components under the influence of $\mathrm{CO}_{2}$ [25]. It is possible that the experimental data obtained for the thermodynamic system will enable accurate prediction of the direction of dynamic change of the carbonation process and allow the design of ways to accelerate the occurring reactions.

Tarkowski \& Manecki [29] and Krupka et al. [16] noticed that thermodynamic data especially for the precipitation of carbonate minerals lacks information on enthalpy $(\Delta H)$, entropy $(\Delta S)$, and Gibbs free energy $(\Delta G)$ for higher temperatures (over $25^{\circ} \mathrm{C}$ ) and common logarithm of the equilibrium constant $\left(\log K_{r}\right)$ for these reactions. Moreover, these values are typically determined for ideal, pure phases, and rarely take into consideration the impurities and substitutions of structure, or solid solution in these minerals. The concentration of a coprecipitate at a known level (e.g. greater than $1 \%$ ) and its presence in the structure can significantly affect the chemical properties, such as solubility of these minerals. What is required following this observation, is the examination of the minerals with the associated phases, which are used in the carbonation process, on a molecular and micro-scale system.

\section{Differential scanning calorimetry (DSC) as a method of mineral carbonation investigation}

Basic methods used in the investigation of carbonation reactions are thermal analysis methods - simultaneous application of thermogravimetry with differential thermal analysis (TG/DTA), supply information on the quantitative composition of the sample and its thermal properties. A less commonly used method is that of thermogravimetry with differential scanning calorimetry (TG/DSC). It is applied to the study of mineral carbonation processes with attention to the reaction energy of the formation and disintegration of carbonate phases. Thermograms provide information about chemical reactions (e.g. oxidation and decomposition), physical processes (e.g. vaporization, sublimation, desorption), and thermal behavior (e.g. exothermic and endothermic reactions). The differential scanning calorimetry (DSC) method is a valuable one in an investigation of the thermal behavior of minerals used in carbonation $[3,4,5,13,28]$. An example of the analysis of carbonation reaction of magnesium silicate by means of thermal methods is given in Fig. 2 [13].

The DSC measures the difference in the amount of heat between the sample and the reference as a function of temperature. DSC is useful in making the same measurements as DTA but has the capability to measure heat capacities and thermal conductivity [15]. Knowing the dependence of the specific heat capacity $C_{p}$ on the temperature $T$, it is possible to determine the enthalpy $\Delta H$ (it is taken as the area under the peak Fig. 2) in certain temperature ranges, and other thermodynamic data (specific heat capacity $C_{p}$, entropy $\Delta S$, the Gibbs free energy $\Delta G$ ). The enthalpy of chemical decomposition is equal in absolute value to the enthalpy of chemical formation. In accordance with this principle it is possible to attempt to calculate the energy of crystallization of mineral carbonation products, by performing experiment under a reactive atmosphere of $\mathrm{CO}_{2}$ for pre-carbonated cement samples, and observing the process following. It is expected that cement submitted to such an experiment will be subject to numerous transformations, gradually undergoing carbonation, and subsequently undergoing the process of decomposition of carbonates. This experiment can lead to simultaneous observation of the reaction, and specific heat measurement $\left(C_{p}\right)$, depending on the temperature changes in the heated sample. Portland cement is a good material due to high $\mathrm{CaO}$ content and detailed knowledge of its thermal behavior. This method can be used for improving knowledge, about the thermodynamic properties of carbonate minerals formed in the process of carbonation.

When $\mathrm{CO}_{2}$ reacts with metal oxides (e.g., calcium, magnesium, or iron) the corresponding carbonate is formed and heat is released. The amount of heat depends on the specific metal 


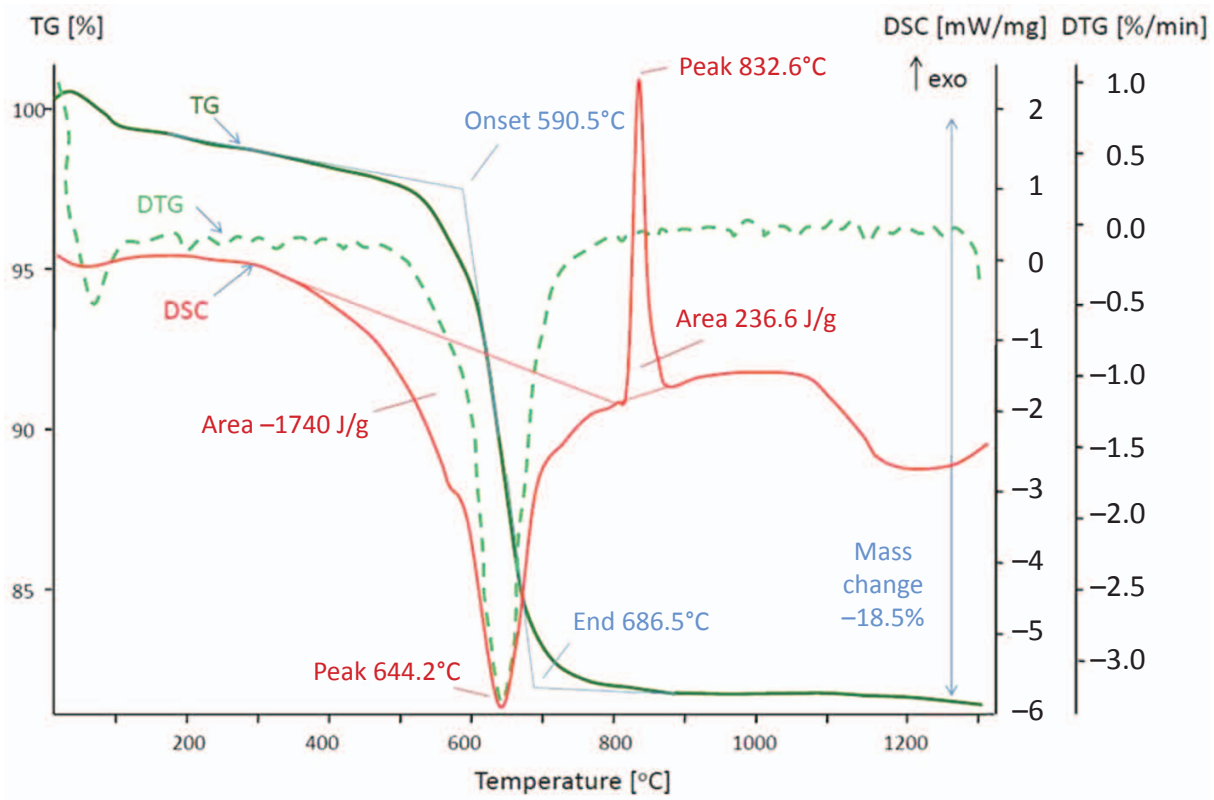

Fig. 2. Carbonation of magnesium silicate minerals: an experimental study by Jia et al. [13]. On the basis of the presented curves (TG, DTG, DSC) it is possible to determine the parameters of the carbonation reaction, including enthalpy
Dubrawski and Warne [5] have already proved in 1988, that DSC can be used to measure enthalpies of mineral phases that otherwise are neither available nor readily established theoretically. Moreover, the accuracy of DSC measurements is limited by the purity of the minerals themselves. DSC is quite sensitive to even low levels of substitution (about 1\%) and to the effects of substitution and that the trend of measured enthalpies is systematic and useful to an understanding of these reactions.

More popular $[21,24,28]$ in determining the enthalpy of solution $\left(\Delta H_{s l n}\right)$ and the enthalpy of crystallization $\left(\Delta H_{c r y s}\right)$ is solution calorimetry (measuring the enthalpy of dropsolution $\Delta H_{\text {dropsolution }}$ ), which keeps the and on the material containing the metal oxide, in this case calcium oxide $\mathrm{CaO}$. In general, this is a large fraction (up to $46 \%$ in the case of calcium oxide) of the heat released by the upstream combustion process forming $\mathrm{CO}_{2}\left(393.8 \mathrm{~kJ} \mathrm{~mol}^{-1} \mathrm{CO}_{2}\right.$ for combustion of elemental carbon) [19]. In thermal method i.e. differential scanning calorimetry (DSC) this heat is manifested as exothermic reactions and peaks visibly on the DSC curves, which can be used to calculate enthalpies of this transition, using the following equation:

$$
\Delta H=K \cdot A
$$

where $\Delta H$ is the energy $(\mathrm{mJ} / \mathrm{mg}$ ) for a given thermal process, $K$ is the calorimetric constant and $A$ the peak area normalized to energy values [5]. The DSC curves recorded simultaneously with TG curves give the enthalpies associated with reactions such as dehydration, crystallization, and decomposition, occurring in carbonate materials, such as cement. reaction in the solution, either at a low temperature in aqueous solution or at a high temperature in oxide melt solvent. Low temperature calorimetry is used to measure the heat of the process at low temperature, such as freezing and crystallization. The temperature range is from $-200^{\circ} \mathrm{C}$ to $200^{\circ} \mathrm{C}$; as the solvent - aqueous acid and base are used e.g. aqueous solution of $\mathrm{HCl}$ and $\mathrm{NaOH}$. The high temperature drop solution calorimetry works at $700^{\circ} \mathrm{C}$ and $800^{\circ} \mathrm{C}$ using sodium molybdate, lead borate and alkali borate as solvents. It has been used to measure the heat contents, enthalpy of formations, enthalpy of phase transitions, enthalpy of dehydration, enthalpy of oxidation for different oxides, solid solutions, and minerals [9]. The data obtained are important in understanding the phase relations of carbonates in geochemical systems and thus are important for the accurate geochemical reaction modeling of $\mathrm{CO}_{2}$ sequestration systems and mineral trapping reactions [16].

\section{Conclusions}

The mechanism of $\mathrm{CO}_{2}$ sequestration is recognized so far, primarily in geological space, in the ecological and economic sense. The trend started by some researchers, recommending that the thermodynamic system of chemical reactions and physicochemical processes, should be continued. Examining the mechanism of mineral sequestration of $\mathrm{CO}_{2}$ on a molecular scale may maximize the effectiveness of carbonation. The determined kinetic and thermodynamic data can be used in the future for modeling mineral carbonation under certain conditions, both during and after the process of carbonation.
There is the need to conduct extensive research which will contribute to the detailed knowledge of mineral carbonation process and identify opportunities to accelerate the carbonation reaction. The proposed studies of the kinetic and thermodynamic data concerning mineral products of carbonation will allow to estimate the $\mathrm{CO}_{2}$ sequestration potential of cement material, and in consequence, to reduce the concentration of $\mathrm{CO}_{2}$ in the atmosphere.

This study pays attention to the possibility of the improvement of the effectiveness of mineral carbonation methods 
with the use of waste material, such as cement or concrete (with a high content of Portland cement clinker), in which the reactive compound is $\mathrm{CaO}$. Special attention should be paid to building rubble, which is a common waste material. The use of such material is suitable not only for economical reasons, but mainly because of the good quality and composition of cement material. Future studies should focus on the estimation of the $\mathrm{CO}_{2}$ sequestration potential of cement material. Although the mechanism of mineral sequestration is considered to be the safest and most durable in the context of the binding of carbon dioxide, the reaction rate is quite slow. Moreover, in contrast to most literature on the subject, it is suggested to use thermogravimetry with differential scanning calorimetry (TG/DSC) method in $\mathrm{CO}_{2}$ atmosphere as a good way to extend knowledge about thermodynamics and energy of formation and disintegration reactions. To improve the fundamental understanding of the mineral carbonation process within cement material, there is the need to identify the crystallization energetics of the reaction in specified pressure and temperature conditions. For the calculation of parameters such as specific heat $C_{p}$, enthalpy $\Delta H$, entropy $\Delta S$, as well as Gibbs free energy $\Delta G$, differential scanning calorimetry (TG/DSC) could be used. This method can in some cases be an alternative to the complicated method of solution calorimetry, which measures the enthalpy of dropsolution $\Delta H_{\text {dropsolution }}$ (solution and crystallization). Moreover the DSC measurement enables the analysis under different atmospheric conditions (e.g. inert gas, air, aggressive atmosphere of $\mathrm{CO}_{2}$, with different heating rates, etc), providing essential knowledge about the course of the carbonation reaction. Additionally in this consideration it is shown, that the understanding of the carbonation process is still a considerable problem, which should be considered, not only on a large scale, but also on a micro- and molecular scale.

Please cite as: Nafta-Gaz 2015, no. 12, pp. 998-1004, DOI: 10.18668/NG2015.12.08

Article contributed to the Editor 17.06.2015. Approved for publication 28.07.2015.

The present work was prepared at the Silesian University of Technology during the period from March 2013 to December 2014.

\section{Literature}

[1] Balucan R. D., Dlugogorski B. Z., Kennedy E. M., Belova I. V., Murch G. E.: Energy cost of heat activating serpentinites for $\mathrm{CO}_{2}$ storage by mineralisation. International Journal of Greenhouse Gas Control 2013, vol. 17, pp. 225-239.

[2] Bertos M. F., Simons S. J. R., Hills C. D., Carey P. J.: A review of accelerated carbonation technology in the treatment of cement-based materials and sequestration of $\mathrm{CO}_{2}$. Journal of Hazardous Materials 2004, B112, pp. 193-205.

[3] Chang E. E., Wang Y. C., Pan S. Y., Chen Y. H., Chiang P. C.: $\mathrm{CO}_{2}$ capture by using blended hydraulic slag cement via a slurry reactor. Aerosol and Air Quality Research, 2012, vol. 12, pp. 1433-1443.

[4] Chedella S. C., Berzins D. W.: A differential scanning calorimetry study of thesetting reaction of MTA. International Endodontic Journal, 2010, vol. 43, pp. 509-518.

[5] Dubrawski J. V., Warne S. St. J.: Differential scanning calorimetry of minerals of the dolomite-ferroan-dolomite-ankerite series in flowing carbon dioxide. Mineralogical Magazine 1988, vol. 52, pp. 627-635.

[6] Fernández Bertos M., Simons S. J. R., Hills C. D., Carey P. J.: A review of accelerated carbonation technology in the treatment of cement-based materials and sequestration of $\mathrm{CO}_{2}$. Journal of Hazardous Materials 2004, B112, pp. 193-205.

[7] Fujii M., Yamasaki A., Kakizawa M., Yanagisawa Y.: Reduction of $\mathrm{CO}_{2}$ emission by treatment of waste concrete via an artificial process. Symposium - American Chemical Society, Division Fuel Chemistry 2001, vol. 46, no. 1, pp. 75-77.

[8] Garcia S., Rosenbauer R. J., Palandri J., Maroto-Valer M. M.: Sequestration of non-pure carbon dioxide streams in iron oxyhydroxide-containing saline repositories. International Journal of Greenhouse Gas Control 2012, vol. 7, pp. 89-97.

[9] Hemminger W., Höhne G.: Calorimetry - Fundamentals and Practice. Verlag Chemie, Weinheim 1984, pp. 275-279.

[10] Huijgen W. J. J., Comans R. N. J.: Carbon dioxide sequestra- tion by mineral carbonation. Petten. NL: Energy Research Centre of the Netherlands, 2003.

[11] Huntzinger D. N., Gierke J. S., Kawatra S. K., Eisele T. C., Sutter L. L.: Carbon dioxide sequestration in cement kiln dust through mineral carbonation. Environmental Science \& Technology 2009, vol. 43, pp. 1986-1992.

[12] Huntzinger D. N., Gierke J. S., Sutter L. L., Kawatra S. K., Eisele T. C.: Mineral carbonation for carbon sequestration in cement kiln dust from waste piles. Journal of Hazardous Materials 2009, vol. 168, pp. 31-37.

[13] Jia L., Anthony E. J., Lin W., Ruan Y., Gora D.: Carbonation of Magnesium Silicate Minerals: an Experimental Stu$d y$. The Canadian Journal of Chemical Engineering 2004, vol. 82 .

[14] Junior A. N., Toledo Filho R. D.: $\mathrm{CO}_{2}$ sequestration by high initial strength Portland cement pastes. Journal of Thermal Analysis and Calorimetry 2013, vol. 113, pp. 1577-1584.

[15] Klančnik G., Medved J., Mrvar P.: Differential thermal analysis (DTA) and differential scanning calorimetry (DSC) as a method of material investigation. Materials and Geoenvironment 2010, vol. 57, no. 1, pp. 127-142.

[16] Krupka K. M., Cantrell K. J., McGrail B. P.: Thermodynamic Data for Geochemical Modeling of Carbonate Reactions Associated with $\mathrm{CO}_{2}$ Sequestration - Literature Review. Report of Pacific Northwest National Laboratory Richland, Washington 99352, 2010.

[17] Labus M.: Proba oceny krajowych zasobow zloz serpentynitu dla celow sekwestracji $\mathrm{CO}_{2}$. Kwartalnik Górnictwo i Geologia 2010, vol. 5, no. 2, pp. 133-141.

[18] Madrawski J., Ziemblinska K., Juszczak R., Zawal D., Olejnik J.: Tradycyjne $i$ alternatywne metody oceny intensywnosci procesu sekwestracji ditlenku wegla przez kruszywo betonowe z recyklingu. Annual Set the Environmental Protection 2013, vol. 15, pp. 2526-2545. 
[19] Mazzotti M.: Mineral carbonation and industrial uses of $\mathrm{CO}_{2}$ IPCC Special Report on Carbon Dioxide Capture and Storage. Eds. Metz B., Davidson O., de Coninck H., Loos M., Meyer L., Cambridge Univ. Press, Cambridge 2005, pp. 319-338.

[20] Montes-Hernandeza G., Renarda F., Geoffroya N., Charleta L., Pironon J.: Calcite precipitation from $\mathrm{CO}_{2}-\mathrm{H}_{2} \mathrm{O}-\mathrm{Ca}(\mathrm{OH})_{2}$ slurry under high pressure of $\mathrm{CO}_{2}$. Journal of Crystal Growth 2007, vol. 308, pp. 228-236.

[21] Navrotsky A., Dooley D., Reeder R., Brady P.: Calorimetric studies of the energetics of order-disorder in the system $\mathrm{Mg}_{\mathrm{I-x}} \mathrm{Fe}_{x} \mathrm{Ca}\left(\mathrm{CO}_{3}\right)_{2}$. American Mineralogist 1999, vol. 84, pp. 1622-1626.

[22] Oelkers E. H., Gislason S. R., Matter J.: Mineral carbonation of $\mathrm{CO}_{2}$. Elements 2008, vol. 4, pp. 333-337.

[23] Radha A. V., Fernandez-Martinez A., Huc Y., Jun Y-S., Waychunas G. A., Navrotsky A.: Energetic and structural studies of amorphous $\mathrm{Ca}_{1-x} \mathrm{Mg}_{x} \mathrm{CO}_{3} \times{ }_{n} \mathrm{H}_{2} \mathrm{O}(0 \leq x \leq 1)$. Geochimica et Cosmochimica Acta 2011, vol. 90, pp. 83-95.

[24] Radha A. V., Forbesa T. Z., Killianb C. E., Gilbert P. U. P. A., Navrotskya A.: Transformation and crystallization energet$i$ ics of synthetic and biogenic amorphous calcium carbonate. PNAS 2010, vol. 107, pp. 38.

[25] Regnault O., Lagneau V., Schneider H.: Experimental measurement of portlandite carbonation kinetics with supercritical $\mathrm{CO}_{2}$. Chemical Geology 2009, vol. 265, pp. 113-121.

[26] Rendek E., Ducom G., Germain P.: Carbon dioxide sequestration in municipal solid waste incinerator (MSWI) bottom ash. Journal of Hazardous Materials 2006, B128, pp. 73-79.
[27] Rozanski P., Pogorzalek J., Stecko J., Zdonek B., Niesler M., Spiewok W.: Badania nad procesem sekwestracji $\mathrm{CO}_{2}$ w zlozach mineralnych z wykorzystaniem zuzli metalurgicznych. Prace Instytutu Metalurgii Żelaza 2011, no. 1, pp. 55-59.

[28] Sel O., Radha A. V., Dideriksen K., Navrotsky A.: Amorphous iron (II) carbonate: Crystallization energetics and comparison to other carbonate minerals related to $\mathrm{CO}_{2}$ sequestration. Geochimica et Cosmochimica Acta 2012, vol. 87, pp. 61-68.

[29] Tarkowski R., Manecki M.: Badania oddzialywania $\mathrm{CO}_{2}$ na mezozoiczne skaly zbiornikowe $w$ celu okreslenia ich przydatnosci do geologicznej sekwestracji dwutlenku wegla. Wydawnictwo Instytutu GSMiE PAN, Kraków 2009, pp. 1-114.

[30] Uliasz-Bochenczyk A., Mazurkiewicz M., Mokrzycki E., Piotrowski Z.: Utylizacja ditlenku węgla poprzez mineralna karbonatyzację. Polityka Energetyczna 7. Zeszyt specjalny, Wydawnictwo Instytutu GSMiE PAN, Kraków 2004, pp. 541-554.

[31] Uliasz-Bochenczyk A.: Mineralna sekwestracja $\mathrm{CO}_{2}$ przy zastosowaniu zawiesin wodnych wybranych popiolow lotnych ze spalania wegla brunatnego. Gospodarka Surowcami Mineralnymi 2011, t. 27, pp. 145-154.

[32] White C. M., Strazisar B. R., Granite E. J., Hoffman J. S., Pennline H.: Separation and Capture of $\mathrm{CO}_{2}$ from Large Stationary Sources and Sequestration in Geological Formations-Coalbeds and Deep Saline Aquifers. Journal of the Air \& Waste Management Association 2003, vol. 53, no. 6, pp. 645-715.

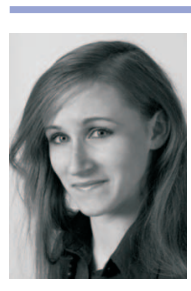

Małgorzata LEMPART M.Sc. Eng.

A doctoral student at the Institute of Geological

Sciences

Polish Academy of Sciences

Research Centre in Cracow

ul. Senacka 1, 31-002 Kraków

E-mail: ndlempar@cyf-kr.edu.pl

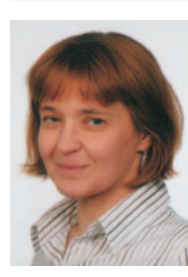

Dr. hab. Eng. Małgorzata LABUS

Assistant Professor

Faculty of Mining and Geology

Silesian University of Technology

ul. Akademicka 2

44-100 Gliwice

E-mail: malgorzata.labus@polsl.pl 